Prepared for the U.S. Department of Energy

under Contract DE-AC05-76RL01830

\title{
Climate Policy Implications for Agricultural Water Demand
}

\author{
V Chaturvedi MI Hejazi \\ JA Edmonds LE Clarke \\ GP Kyle \\ E Davies \\ MA Wise \\ KV Calvin
}

March 2013

Pacific Northwest

NATIONAL LABORATORY

Proudly Operated by Battelle Since 1965 


\section{DISCLAIMER}

This report was prepared as an account of work sponsored by an agency of the United States Government. Neither the United States Government nor any agency thereof, nor Battelle Memorial Institute, nor any of their employees, makes any warranty, express or implied, or assumes any legal liability or responsibility for the accuracy, completeness, or usefulness of any information, apparatus, product, or process disclosed, or represents that its use would not infringe privately owned rights. Reference herein to any specific commercial product, process, or service by trade name, trademark, manufacturer, or otherwise does not necessarily constitute or imply its endorsement, recommendation, or favoring by the United States Government or any agency thereof, or Battelle Memorial Institute. The views and opinions of authors expressed herein do not necessarily state or reflect those of the United States Government or any agency thereof

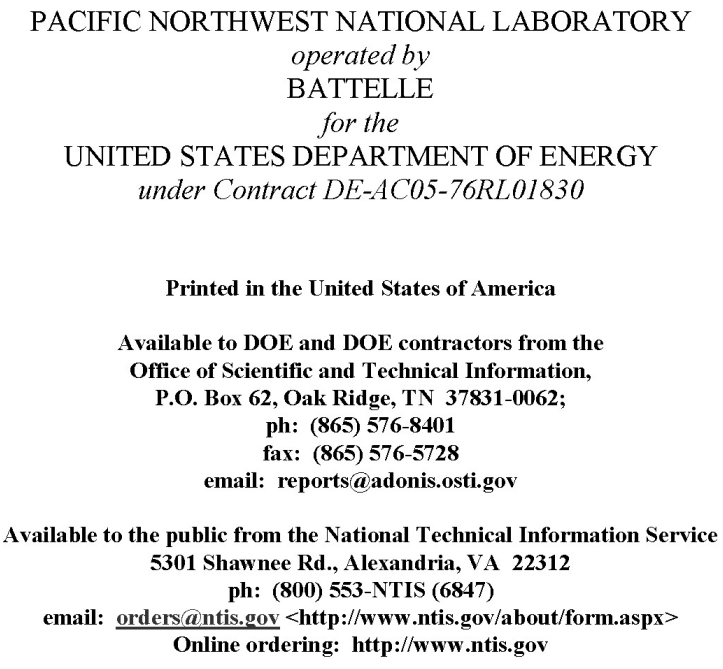

This document was printed on recycled paper. 



\section{Climate policy implications for agricultural water demand}

Vaibhav Chaturvedi ${ }^{\mathrm{a}, 1}$, Mohamad Hejazi ${ }^{\mathrm{a}}$, James Edmonds ${ }^{\mathrm{a}}$, Leon Clarke ${ }^{\mathrm{a}}$, Page Kyle ${ }^{\mathrm{a}}$, Evan Davies $^{\mathrm{b}}$, Marshall Wise ${ }^{\mathrm{a}}$, Katherine Calvin ${ }^{\mathrm{a}}$

a Joint Global Change Research Institute, College Park, MD, USA

${ }^{\mathrm{b}}$ Department of Civil and Environmental Engineering, University of Alberta, Edmonton, Alberta, Canada

\section{DISCUSSION PAPER}

Please send your comments to vaibhav.chaturvedi@pnnl.gov

\footnotetext{
${ }^{1}$ Corresponding author, E-mail: vaibhav.chaturvedi@pnnl.gov , Tel: +1-301-405-0898
} 


\begin{abstract}
Energy, water and land are scarce resources, critical to humans. Developments in each affect the availability and cost of the others, and consequently human prosperity. Measures to limit greenhouse gas concentrations will inevitably exact dramatic changes on energy and land systems and in turn alter the character, magnitude and geographic distribution of human claims on water resources. We employ the Global Change Assessment Model (GCAM), an integrated assessment model to explore the interactions of energy, land and water systems in the context of alternative policies to limit climate change to three alternative levels: $2.5 \mathrm{Wm}^{-2}$ (445 $\mathrm{ppm}^{-\mathrm{CO}_{2}}$ e), $3.5 \mathrm{Wm}^{-2}$ (535 $\mathrm{ppm} \mathrm{CO}_{2}$-e) and $4.5 \mathrm{Wm}^{-2}$ (645 $\mathrm{ppm} \mathrm{CO}_{2}$-e). We explore the effects of two alternative land-use emissions mitigation policy options-one which taxes terrestrial carbon emissions equally with fossil fuel and industrial emissions, and an alternative which only taxes fossil fuel and industrial emissions but places no penalty on land-use change emissions. We find that increasing populations and economic growth could be anticipated to almost triple demand for water for agricultural systems across the century even in the absence of climate policy. In general policies to mitigate climate change increase agricultural demands for water still further, though the largest changes occur in the second half of the century, under both policy regimes. The two policies examined profoundly affected both the sources and magnitudes of the increase in irrigation water demands. The largest increases in agricultural irrigation water demand occurred in scenarios where only fossil fuel emissions were priced (but not land-use change emission) and were primarily driven by rapid expansion in bioenergy production. In these scenarios water demands were large relative to present-day total available water, calling into question whether it would be physically possible to produce the associated biomass energy. We explored the potential of improved water delivery and irrigation system efficiencies. These could potentially reduce demands substantially. However, overall demands remained high under our fossil-fuel-only tax policy. In contrast, when all carbon was priced, increases in agricultural water demands were smaller than under the fossil-fuel-only policy and were driven primarily by increased demands for water by non-biomass crops such as rice. Finally we estimate the geospatial pattern of water demands and find that regions such as China, India and other countries in south and east Asia might be expected to experience greatest increases in water demands.
\end{abstract}




\section{Introduction}

Energy, water and land are scarce resources, critical to human prosperity. Developments in each affect the availability and cost of the others. Measures to limit greenhouse gas concentrations will inevitably exact major changes on energy and land systems and in turn alter the character, magnitude and geographic distribution of human claims on water resources.

Measures to limit greenhouse gas concentrations will inevitably deliver dramatic changes to energy and land systems (Nakicenovik and Swart, 2000; Clarke et al., 2007; Syri et al., 2008; Calvin et al., 2009; Clarke, et al., 2009; Wise, et al., 2009; Edmonds et al., 2012; Grassi et al., 2012; van Vuuren, et al. 2012). Those changes in turn will inevitably alter the character, magnitude and geographic distribution of human claims on water resources, which in turn may limit mitigation options. In this paper we begin to explore those interconnections.

The focus of this paper is on the emissions mitigation climate policy implications for agricultural fresh water demands. Understanding agricultural water demands is critical to understanding both emissions mitigation policy and fresh water in general. Agriculture accounts for 70 percent of global freshwater withdrawals (FAO, 2003; Rost et al., 2008) and 92\% percent of global freshwater consumption (Hoekstra and Mekonnen, 2012), climate policy implications for agricultural water resource use constitutes an important consideration in policy formulation that is only beginning to be appreciated.

While this paper explores a new research question, it builds on the foundation of previous studies. For example, Postel (1998), Döll (2004), Rosegrant et al. (2002), Rost et al. (2008), Wisser et al. (2008), The 2030 Water Resources Group (2009), Fader et al. (2010), Liu and Yang (2010), Seibert and Döll (2010), Hanasaki et al. (2010), Hanjra and Qureshi, (2010), and de Fraiture and Wichelns (2010) examined potential future global and regional agricultural demands for water. Other studies examined the demand for water implied by potential expansion of bioenergy crop production in response to climate mitigation policies. See for example, Berndes (2002), Brendes (2008), Gerbens-Leenes et al. (2009), and Varghese (2007).

We employ the Global Change Assessment Model (GCAM), an integrated assessment model, which was developed and is maintained at the Pacific Northwest National Laboratory's (PNNL) Joint Global Change Research Institute (JGCRI), to assess the climate policy implications for agricultural fresh water demands, because it offers an integrated global and regional analysis framework that closely couples energy, water and land. GCAM enables us to consistently capture the complex interactions between economic and demographic factors, energy systems, land use profiles, and emission mitigation policies, allowing analysis of their effects on the longterm evolution of irrigation water demand under various climate policy scenarios.

To explore possible changes in irrigation requirements with rising population, crop- and bioenergy production, scenarios of irrigation water demand in GCAM are analyzed for different crop categories in various regions of the world. The paper analyzes two important research questions- i) how large may global irrigation water demands grow, and ii) what are the potential impacts of emissions mitigation policies on global irrigation-water withdrawals. 


\section{Approach}

To assess the consequence of climate mitigation policies on agricultural water demand, we develop a set of scenarios that begins with a reference scenario. The reference scenario is a counterfactual scenario in which demographic, economic and technology developments occur in the absence of policies primarily designed to reduce greenhouse gas emissions.

We compare our reference scenario to a set of scenarios that are identical except that they explicitly assume particular climate policy interventions. These interventions are distinguished by two characteristics: Degree of stringency and Policy instrument.

- Degree of stringency: We examine three degrees of stringency defined in terms of the maximum end-of-century radiative forcing-Watts per meter squared $\left(\mathrm{Wm}^{-2}\right)$, including the effect of all greenhouse gases, aerosols and short-lived species:

$$
\begin{array}{ll}
\circ & 4.5 \mathrm{Wm}^{-2}\left(645 \mathrm{ppm} \mathrm{CO}_{2-\mathrm{e}}\right), \\
\circ & 3.5 \mathrm{Wm}^{-2}\left(535 \mathrm{ppm} \mathrm{CO}_{2-\mathrm{e}}\right) \text {, and } \\
\circ & 2.5 \mathrm{Wm}-2\left(445 \mathrm{ppm} \mathrm{CO}_{2-\mathrm{e}}\right) .
\end{array}
$$

- Policy instrument: We limit radiative forcing by imposing a carbon tax on greenhouse gas emissions. The carbon tax is imposed on all fossil fuel and industrial emissions and on non- $\mathrm{CO}_{2}$ emissions valued using 100-year Global Warming Potential Coefficients ${ }^{2}$. In all of our scenarios we assume immediate participation by all regions of the world, which are assumed to share a common carbon price, which rises at the Hotelling-Peck-Wan rate $^{3}$

Land use policy has been shown to be important in shaping bioenergy production. See for example, McCarl and Schneider (2001), Azar (2005), Rokityanskiy, et al. (2007), Gillingham et al. (2008), Wise, et al. (2009), Mellilo, et al. (2009), and many others. Here we explore two alternative assumptions about land-use climate policy instruments. The first values terrestrial emissions at the same price as fossil fuel and industrial emissions - the Universal Carbon Tax (UCT). The second leaves terrestrial carbon emissions un-priced-the Fossil Fuel and Industrial Carbon Tax (FFICT) ${ }^{4}$.

To clearly identify the effects of emissions mitigation policies on the demand for water we ignore the feedback effects of climate change and $\mathrm{CO}_{2}$ concentrations on crop yields and water demands. While these effects have been shown to be significant, (IPCC, 2007), including these effects potentially cloud effects of emissions mitigation, the focus of this paper.

\section{The GCAM framework}

\footnotetext{
2 The global warming potentials are based on Ehhalt et al. (2001)

${ }^{3}$ See Hotelling (1931) and Peck and Wan (1996) for a discussion of the cost-minimizing rate of escalation of the carbon price. Calvin, et al. (2009) explore the implications for agriculture, land use, and land-use change emissions of relaxing the assumption that all regions initiate emissions mitigation simultaneously.

${ }^{4}$ See Wise, et al. (2009) for further discussion of these policy assumptions and their land-use implications.
} 
We employ GCAM 3.0 an integrated assessment model (IAM) of human and biogeophysical Earth system processes relevant to climate change to conduct our numerical experiments (Wise and Calvin, 2011). GCAM tracks emissions, atmospheric disposition, radiative and climate effects of 16 greenhouse gases, aerosols and short-lived species ${ }^{5}$. GCAM is a dynamic-recursive model, which links a global energy-economy-agriculture-land-use model with a climate model of intermediate complexity. The human Earth system components of GCAM are direct descendants of the Edmonds-Reilly model (Edmonds and Reilly, 1985). GCAM subdivides the world into fourteen regions and operates from 2005 to 2095 in five-year increments. The agriculture and terrestrial system (Wise and Calvin, 2011 and Kyle, et al., 2011) further subdivides each of the GCAM's fourteen geopolitical regions into as many as eighteen sub-regions, based on the agroecological zones described by Monfreda et al. (2009). We refer to these as agro-ecological zones (AEZs).

The GCAM simultaneously determines a consistent set of market-clearing prices for all energy, agricultural and forest products. GCAM computes the supply and demand for primary energy forms (e.g., coal, natural gas, crude oil), secondary energy products (e.g., electricity, hydrogen, refined liquids), several agricultural products (e.g., corn, wheat, rice, beef, poultry, etc.) and three different sources of bioenergy supply (a cellulosic crop, crop residues, and municipal solidwaste) (Luckow et al., 2010). The GCAM model assumes global trade in fossil fuels and agricultural products, and tracks emissions of a full suite of gases and reactive substances from a variety of human activities. GCAM 3.0 was released in November 2011 and incorporates major revisions to the representation of agriculture, land-use, and terrestrial carbon cycle as well as introduced regionally specific graded geologic $\mathrm{CO}_{2}$ storage capacity endowments.

All of the scenarios modeled here share the same economic, demographic, natural resource and other critical assumptions described by Thomson et al. (2011). In particular, all scenarios assume a global population that grows until mid-century, peaks in 2065, and declines to approximately 9 billion between 2065 and 2100. Living standards continue to increase and technological improvements in the production of energy, energy-related services, and agricultural goods continue to occur throughout the century.

In this paper we supplement the release version of GCAM 3.0 with methods to estimate the demand for fresh water for agricultural purposes as discussed below.

\section{Modeling the demand for fresh water}

All crops require water to grow. Much of the water utilized by crops comes in the form of rain and imposes no net claim on water that could be put to other uses. When rainfall is insufficient in quantity or time, it can be supplanted by withdrawing water from the rivers, lakes and aquifers. Those withdrawals in turn limit access by others to the use of that water. All water that is withdrawn is not consumed. Water returned to freshwater reservoirs can be used by others. We therefore track both fresh water withdrawals (amounts taken out of fresh water reservoirs)

\footnotetext{
${ }^{5}$ This paper focuses primarily on $\mathrm{CO}_{2}$ emissions and concentrations. This is due to a need for brevity. However, GCAM tracks all 16 species and radiative forcing calculations include the effects of emissions and concentrations from all emissions sources.
} 
and consumption (water removed from fresh water reservoirs and not returned, i.e. evaporated back to the atmosphere). See Shiklomanov (2000).

Our estimate of the demand for fresh water (irrigation) begins with an estimate of the total water required by crops, biophysical water consumption (WC) which is the product of the rate of water consumptions, virtual water content (VWC), by each plant and the scale of production, $\mathrm{P}$.

We measure WC in $\mathrm{m}^{3}$ per year. We measure $\mathrm{P}$ in tons. And, we measure VWC in $\mathrm{m}^{3} /$ ton. This approach follows Chapagain and Hoekstra (2004) and Mekonnen and Hoekstra (2010).

VWC is the amount of water consumed by a crop during its biophysical growth process and varies across crops and regions.

Thus, biophysical water consumption (WC) can be defined as:

$$
W C=V W C \cdot P
$$

(Equation 1)

Note that biophysical water consumption is a term used to refer to the water required for growing crops irrespective of the source of water, and is required for evapotranspiration by plants during the process of biomass production, from sowing to harvesting, when there is no shortage of water (Chapagain and Hoekstra, 2004). The term includes water required for growing crops in rainfed as well as irrigated areas. Thus for any region:

$$
W C=W C^{R F}+W C^{I R}
$$

On irrigated crop lands, some of the plants' water use comes directly from the soil column (green water) and when insufficient, additional water is generally supplied in the form of irrigation (blue water; Rockstrom et al., 2009). Green water is the water from precipitation, which is either used directly by crops during the rainfed cropping season or is stored as soil moisture to be used in the irrigated season. Blue water is the water required for irrigation and needs to be withdrawn from rivers, lakes, dams and other surface or groundwater reservoirs.

$$
W C^{I R}=W C_{G}^{I R}+W C_{B}^{I R}
$$

Crop water consumption on rainfed lands $\left(W C^{R F}\right)$ is strictly green water. Thus, the total water consumption can be divided into three components: green water on rainfed areas, green water on irrigated areas, and blue water on irrigated areas. Equation 2 can then be rewritten as:

$$
W C=W C_{G}^{R F}+\underbrace{W C_{G}^{I R}+W C_{B}^{I R}}_{W C^{I R}}
$$

To estimate blue water, green water must be subtracted from the total water consumption on irrigated areas. Green water from precipitation is used predominantly in the monsoon season and the residual green water available as soil moisture is used in the irrigated season. This residual green water per unit of irrigated area is assumed to be constant $(\mathrm{G})^{6}$ across time, calculated from 2005 data, although it varies across crops and AEZs within a region.

$$
G=\frac{W C_{I R}^{G}}{A \cdot \delta_{A}}
$$

\footnotetext{
${ }^{6}$ It should be noted that with climate change impacts, the green water per unit area could change with changing precipitation, however climate change impacts are outside the scope of present analysis.
} 
where $\mathrm{A}$ is the total cropland area and $\delta_{A}$ is the share of that total area that is irrigated. Thus, in this study, we assume that the amount of green water available per unit area of a particular crop and AEZ in the irrigated season is fixed, and blue water is the additional amount of water required by crops after all the green water available is consumed. Blue water withdrawals for irrigated areas can be estimated by rearranging equation 3 , and combining equations 1 and 5:

$$
W C_{B}^{I R}=V W C \cdot P \cdot \delta_{P}-G \cdot A \cdot \delta_{A}
$$

(Equation 6)

where $\delta_{P}$ is the share of production from irrigated lands.

Not all the water withdrawn reaches the agricultural fields, as a significant portion is wasted in the form of efficiency losses in the irrigation conveyance system. Some of that water is returned to the system and is available for others to use and some is lost to evaporation without being used by the plant.

Blue water consumption for each region has been divided by the irrigation water deliveryefficiency factor $(\beta)$ for each region to arrive at the water withdrawal $\left(W W_{B}^{I R}\right)$ by crop within each region.

$$
W W_{B}^{I R}=\frac{W C_{B}^{I R}}{\beta}
$$

The above methodology enables GCAM to produce several quantities for crop water demands: biophysical water consumption (blue and green, $W C$ ), irrigation water consumption (blue water consumption $\left(W C_{B}^{I R}\right)$ and irrigation water withdrawals (blue water withdrawals, $\left.W W_{B}^{I R}\right)$. In Table 1 we compare GCAM's base year (2005) estimates for these three variables with other studies, which used similar approaches for calculating these global quantities (e.g., Mekonnen and Hoekstra, 2011; Siebert and Döll, 2010; Wisser et al., 2008, Döll and Siebert, 2002).

Table1: Comparative agriculture water results across models (in $\mathrm{km}^{3} / \mathrm{yr}$ )

\begin{tabular}{|l|l|c|c|c|}
\hline \multicolumn{1}{|c|}{$\begin{array}{c}\text { Model } \\
\text { Name }\end{array}$} & \multicolumn{1}{|c|}{ Reference } & $\begin{array}{c}\text { Biophysical } \\
\text { water } \\
\text { consumption }\end{array}$ & $\begin{array}{c}\text { Irrigation } \\
\text { water } \\
\text { consumption }\end{array}$ & $\begin{array}{c}\text { Irrigation } \\
\text { water } \\
\text { withdrawals }\end{array}$ \\
\hline DATA & AQUASTAT (2010) & - & 1,121 & 2608 \\
\hline DATA & WRI (2007) & - & 1,143 & 2657 \\
\hline DATA & Chapagain \& Hoekstra (2004) & 6,390 & 1,141 & 2647 \\
\hline DATA & Shiklomanov (2000) & - & 1,741 & 2589 \\
\hline H08 & Hanasaki et al. (2010) & 7,080 & 1,530 & 2810 \\
\hline IMPACT & cited in Calzadilla et al., 2010 & 5,938 & 1,310 & - \\
\hline IMPACT & Rosegrant et al. (2008) & 6,400 & 1,425 & - \\
\hline GCWM & Siebert \& Döll (2010) & 6,685 & 1,180 & 2452 \\
\cline { 2 - 5 } & Liu and Yang (2010) & 7,179 & 1,448 & - \\
\hline GEPIC & Fader et al. (2010) & 6,914 & 927 & - \\
\hline LPJmL & Rost et al. (2008) & 7,243 & 1,364 & - \\
\hline LPJmL & Döll et al. (2003) & - & 1,258 & - \\
\hline WaterGap & & 1,300 & - \\
\hline
\end{tabular}




\begin{tabular}{|l|l|c|c|c|}
\hline WBMplus & Wisser et al. (2010) & - & 1,301 & - \\
\hline WATERsim & Molden (2007) & 6,480 & 1,570 & - \\
\hline \multicolumn{2}{r|}{ This Study } & $\mathbf{6 7 0 9}$ & $\mathbf{9 5 3}$ & $\mathbf{2 3 3 2}$ \\
\hline
\end{tabular}

Note: Our irrigation water consumption estimates do not include fodder crops. Globally, fodder crops use $9 \%$ of global biophysical water consumption (Mekonnen and Hoekstra, 2010).

While differences in methodologies doubtless explain some of the variation in estimates, differences across studies in the time period for which averages were calculated represents an important source of variation. The period over which water demands were calculated varies from 10 to 30 years. Wisser et al. (2008) show that agricultural withdrawals can vary between $2220 \mathrm{~km}^{3}$ and $3100 \mathrm{~km}^{3}$, depending on assumptions related to the base-year irrigated area, growing season pattern, cropping pattern and weather drivers.

In this study, several assumptions are adopted. The virtual water content (VWC) values depend on the crop type, soil characteristics and climate conditions and hence differ for each crop in each region. For bio-energy crops, VWC is based on the values used by Brendes (2002), and it has been assumed that $25 \mathrm{~km}^{3}$ of water is used for producing $1 \mathrm{EJ}$ of energy from biomass - the value used by Brendes $(2002)^{7}$. The VWC values have been assumed to be constant for future years.

Assumptions regarding the shares of crop area under irrigation $\left(\delta_{A}\right)$ and production from irrigated areas $\left(\delta_{P}\right)$ between 2005 and 2095 are based on FAO projections in support of Bruinsma (2009; supporting data provided by author). The FAO projections are run to 2050 and the shares between 2050 and 2095 are extrapolated from the FAO figures. Irrigation delivery efficiency assumptions are based on FAO estimates ${ }^{8}$ and have been used to derive water withdrawal quantity from blue water consumption figures. Efficiency values $(\beta)$ are constant across crops for a region.

For bio-energy crops, the share of area under irrigation and production from irrigated areas have been assumed to be the average of all the other irrigated crops in that region. In this study, we present future projections of crop water demand in terms of water withdrawals only.

\section{Results}

\subsection{Reference scenario (no climate policy)}

Global irrigation water withdrawals almost triple from $2332 \mathrm{~km}^{3}$ in 2005 to $6891 \mathrm{~km}^{3}$ in 2095 , with most of the increase (i.e., 84\%) occurring by 2050 (Figure 1a), and a subsequent increase of only $12 \%$ between 2050 and 2095. Corn, rice and wheat are major consumers of water withdrawals across the century - an unsurprising result since they are also the major crops

\footnotetext{
${ }^{7}$ The VWC of crops varies across regions, and this is probably also true for lignocellulosic bio-energy crops. However, we have also used the same assumption as Brendes (2002) who uses a global average value of VWC 25 $\mathrm{km}^{3} / \mathrm{EJ}$ for bio-energy crops.

${ }^{8}$ http://www.fao.org/nr/water/aquastat/water_use_agr/index 5. stm
} 
produced in the world for meeting food demand. While the water withdrawals for non-energy crops stabilize around 2050, bio-energy crops become the major contributors of the increase in global irrigation water withdrawals in the later decades. The share of bio-energy water withdrawals increase from virtually zero ${ }^{9}$ in 2005 to $13.8 \%$ of global irrigation water withdrawals in 2095 under the reference scenario (Figure 1a). The land use pattern also shows increasing share of dedicated bioenergy crops with these crops being grown on $27 \%$ of the total cropped area in 2095 (Figure 1b).

The increase in irrigation water withdrawals result from three key factors. First, increasing population and per capita income drive crop production increases to meet the food, feed, fiber and other non-food demands. Global population increases by 37\% between 2005 and 2050, but then by less than $1 \%$ between 2050 and 2095. Per capita income continues to rise throughout the century leading to an increase in non-energy crop production by almost $70 \%$ between 2005 and 2050. Second, limited land area coupled with high productivity for irrigated land increases the share of production from the irrigated area (Ozdogan, 2011; McCalla, 2001: Geist and Lambin, 2002). Third, bio-energy production increases for meeting energy needs of the world. The highest yielding bio-energy crops are water-intensive (Brendes, 2002).

\footnotetext{
${ }^{9}$ It should be highlighted that some existing crops are also used in varying degrees for bio-energy, e.g. Corn and Oilcrop in USA, SugarCrop in Latin America and Western Europe. Our numbers represent only dedicated bioenergy crops and exclude water consumption for these traditional crops used for bio-energy. However, this does not affect our estimates of total withdrawals.
} 

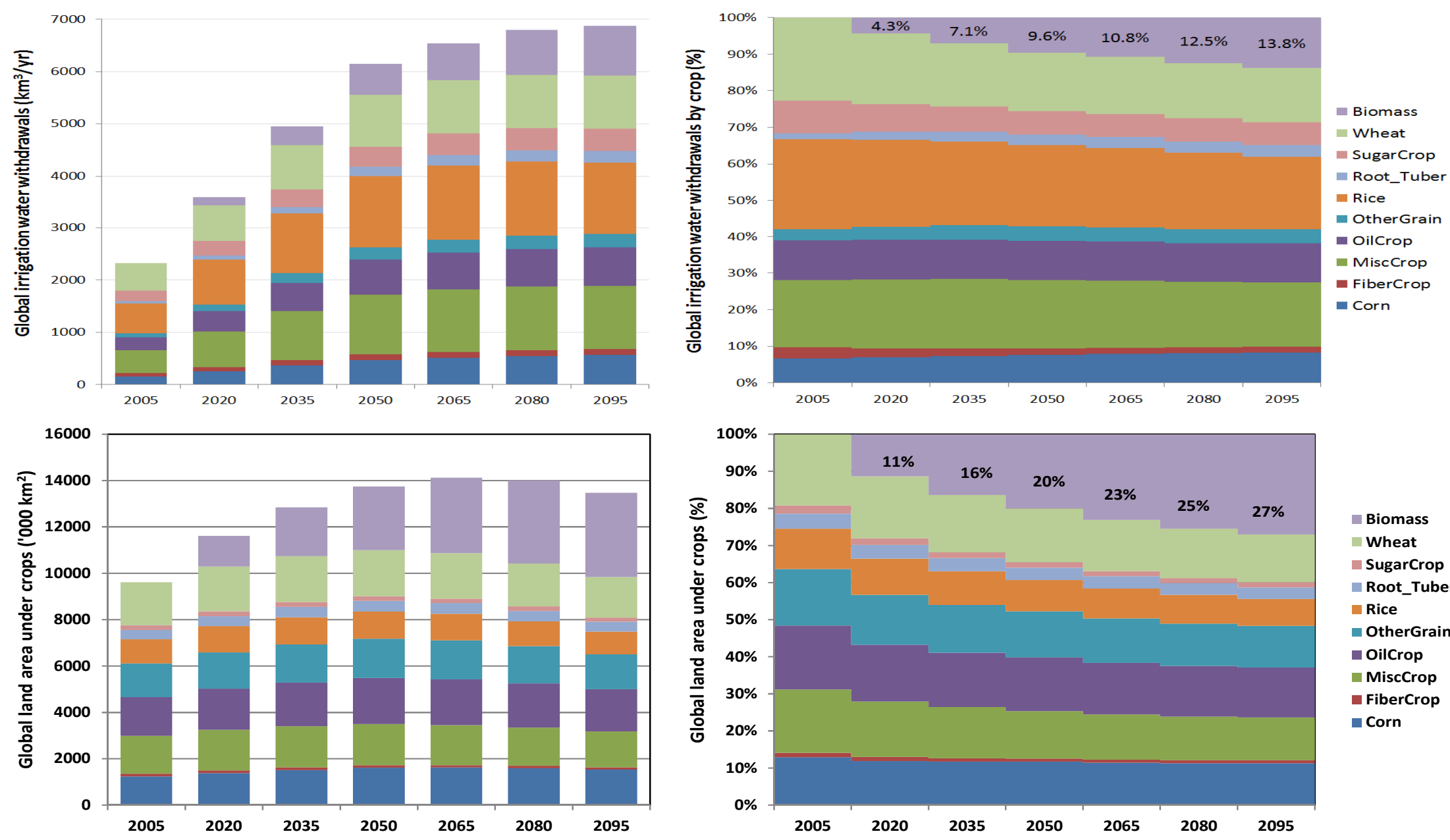

Biomass

Wheat

SugarCrop

Root_Tuber

Rice

- OtherGrain

- OilCrop

MiscCrop

In Fibercrop

- Corn

Figure 1: a) Global irrigation water withdrawals by crops under the BAU scenario; b) Global agriculture land use pattern 


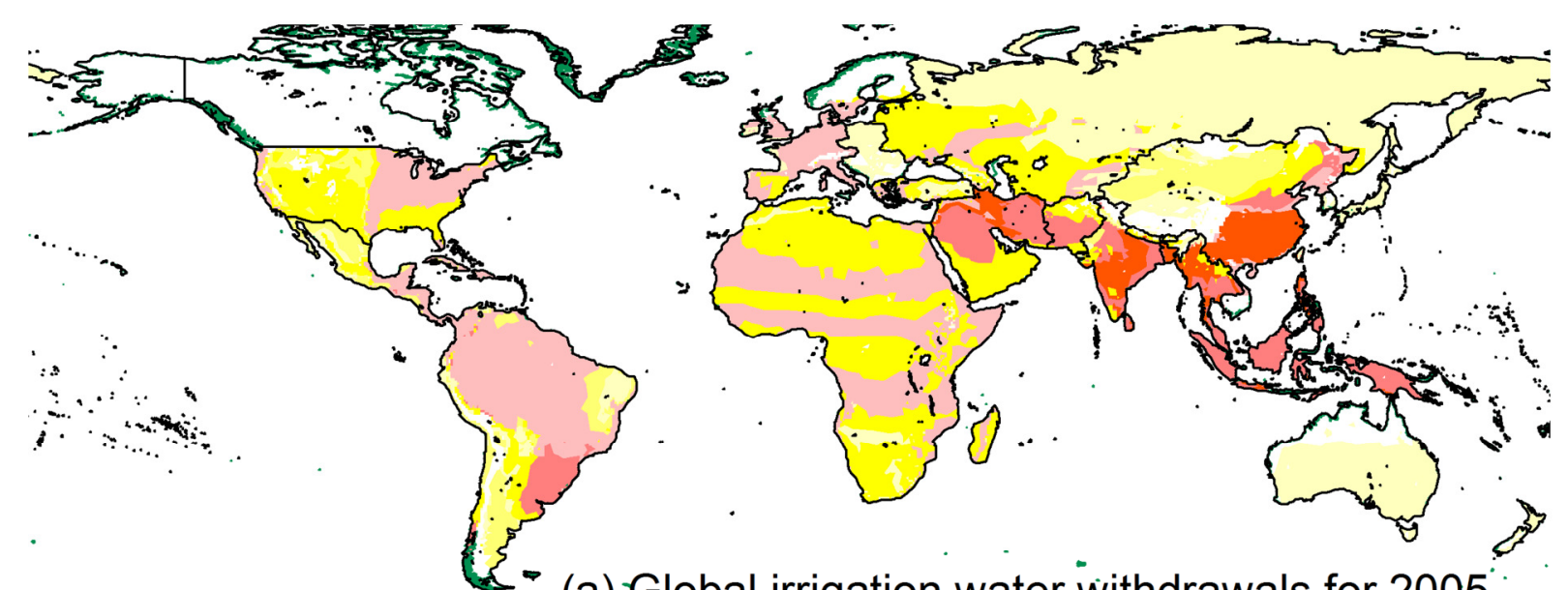

(a) Global irrigation water withdrawals for 2005

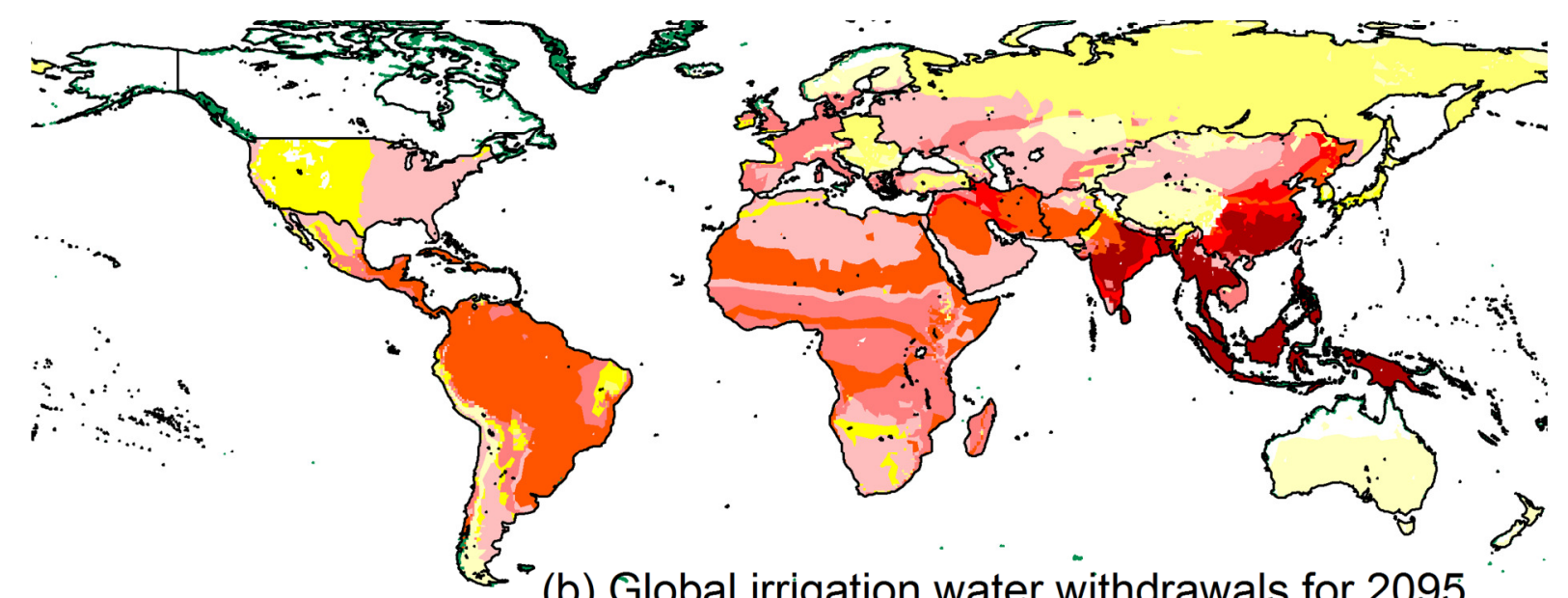

(b) Global irrigation water withdrawals for 2095

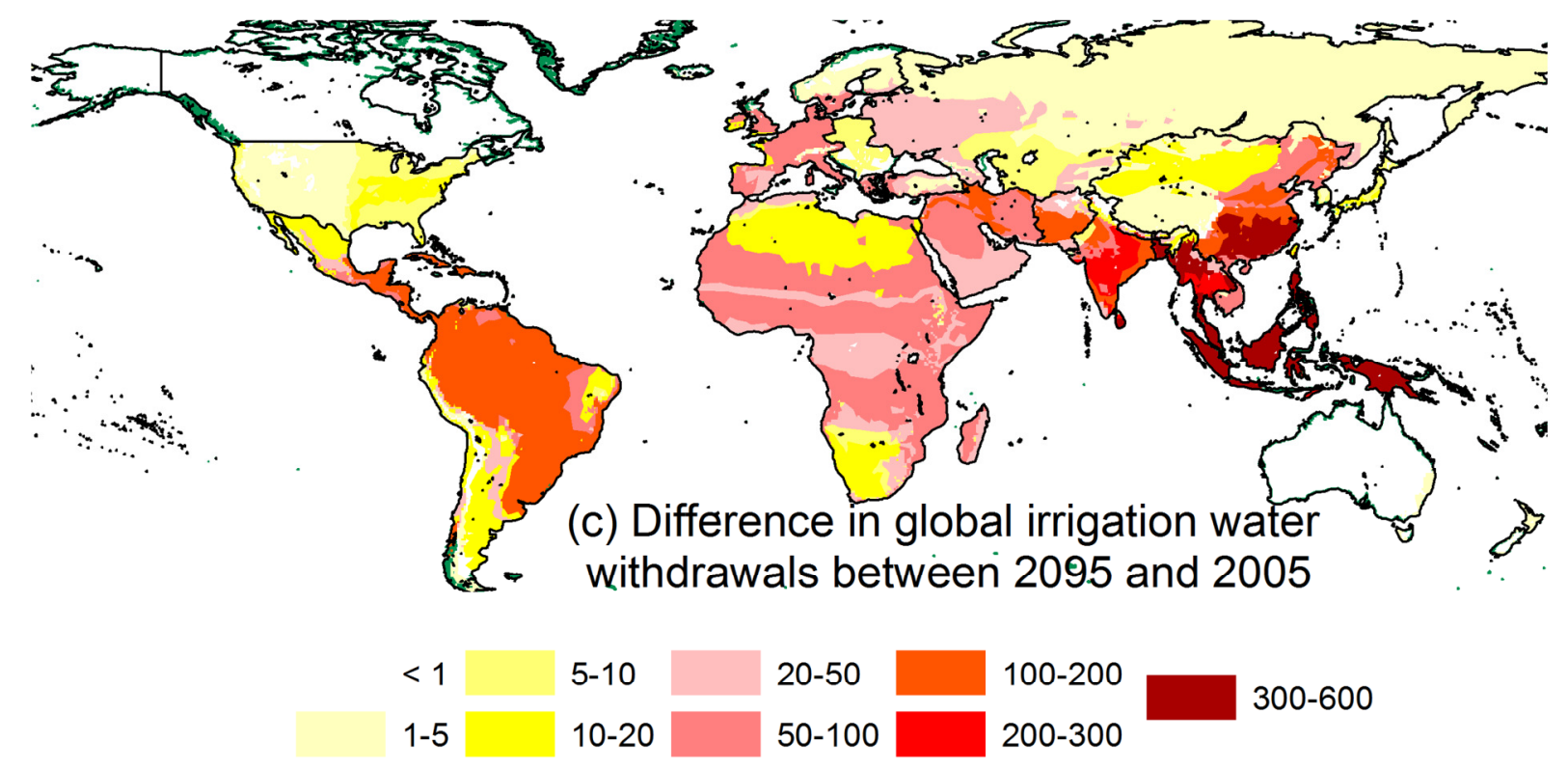

Figure 2: Spatial maps of global irrigation water withdrawals at the AEZ scale (151 regions globally) under the BAU scenario 
GCAM's estimates of future non-bioenergy crop water withdrawals are generally higher than earlier studies (Alcamo et al., 2007; Fischer et al., 2007; Shen et al., 2008). Our higher estimates of agricultural water demand derive from differences between our methods and those employed in other studies. For example, Alcamo et al. (2007) assume constant area under irrigation for their future simulations resulting in no noticeable response to future growing demands for crop products; Shen et al. (2008) simply estimate future irrigation water demands as a function of their assumed future projections of irrigated area; and Fischer et al. (2007) assume that irrigation increases in proportion to increases in irrigated area, and does not seem to address the effects of higher crop productivity changes on irrigated areas and changes in cropping patterns due to dietary shifts on irrigation water demand. Our analysis relaxes some of these assumptions resulting in an upward shift in agricultural water demands. We base our irrigated area and production share estimates on FAO projections (Bruinsma, 2009) and cropping pattern changes are modeled under an economic framework with population, GDP and crop prices as important variables.

Figure 2 shows the regional distribution (151 regions globally) of irrigation water withdrawals in years 2005 and 2095 under the reference scenario. China, India, and parts of Southeast Asia stand out as regions with the maximum water withdrawals in both 2005 and 2095 (Figures 2a and 2b). Although irrigation water withdrawals increase between 2005 and 2095 for almost all regions of the world, the increase is highest for Southeast Asia, followed by China and India (Figure 2c). The bulk of this increase in China is for dedicated bio-energy crops, for Southeast Asia it is for bio-energy crops and rice, and for India it is across many major crops, but bioenergy crops are not included.

\subsection{Emission mitigation policy scenarios}

The imposition of climate policies to limit radiative forcing lead to dramatic land-use change as described in Wise, et al. (2009). Notable changes in terrestrial systems are very different under our UCT (all carbon valued equally) and FFICT (only fossil fuel and industrial carbon emissions are taxed) scenarios. Under the UCT scenarios the value of carbon drives three developments:

- Afforestation - an expansion of carbon in aboveground biomass, leading to shifting of emissions from land use to fossil fuel sector in contrast to the FFICT scenarios, as shown in Figures 3(a) and 3(b),

- Increased bioenergy production in the 2.5 UCT and 3.5 UCT scenarios-since bioenergy is treated as a renewable, non-emitting, energy form, and when used in conjunction with $\mathrm{CO}_{2}$ capture and storage (CCS) can remove carbon from the atmosphere ${ }^{1}$, and

- Dietary shift away from carbon-intensive food (e.g. cattle) driven by the fact that carbon values are incorporated in the rental rate on land and hence into all land-utilizing commodities.

The latter effect is what makes it possible to achieve the first two outcomes since land area cannot expand.

\footnotetext{
${ }^{1}$ In the 4.5UCT scenario bioenergy production actually declines slightly relative to the reference scenario because carbon uptake resulting from afforestation dominates the terrestrial response to increased carbon prices.
} 


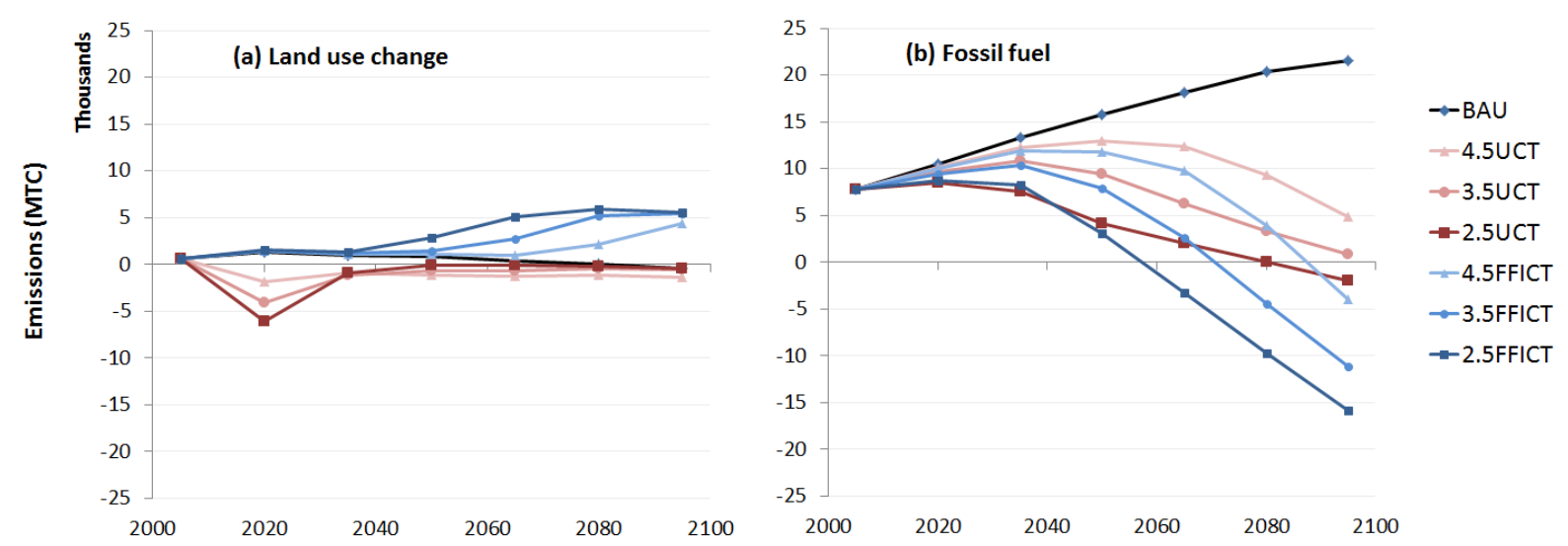

Figure 3: Projections of global emission from (a) land use change and (b) fossil fuel under the BAU and six climate mitigation policy scenarios

Under the FFICT scenarios terrestrial carbon is not valued. Hence,

- There is no incentive to afforest.

- Bioenergy remains attractive since, in fossil fuel and industrial applications it is treated as if it were a renewable, non-emitting energy form and

- Expanded bioenergy production comes predominantly from deforestation rather than dietary shifts.

Under the FFICT scenarios a vicious cycle emerges in which use of bioenergy to reduce fossil fuel and industrial emissions leads to greater land-use emissions, which in turn mean that fossil fuel and industrial emissions must be driven still lower, further increasing deforestation pressures, Figure 3.

These two contrasting policy environments carry dramatically different implications for local and global water demands, Figure 4.

Under the UCT scenarios:

- Total irrigation withdrawals for Non-Energy Crops increase relative to the reference scenario (5-9\% in 2050 and 12-13\% by 2095), Figure 3(a).

- Total irrigation withdrawals for Bioenergy Crops decline, relative to the reference scenario,

- Total irrigation withdrawals for All Agriculture increase slightly (2-7\% in 2050, and 7$11 \%$ in 2095).

Under the FFICT scenarios

- Total irrigation withdrawals for Non-Energy Crops increase very little relative to the reference scenario.

- Total irrigation withdrawals for Bioenergy Crops relative to the reference scenario increase dramatically (27-208\% in 2050 and 473-1,025\% in 2095).

- Total irrigation withdrawals for All Agriculture increase dramatically (3-20\% in 2050, and $65-141 \%$ in 2095). 

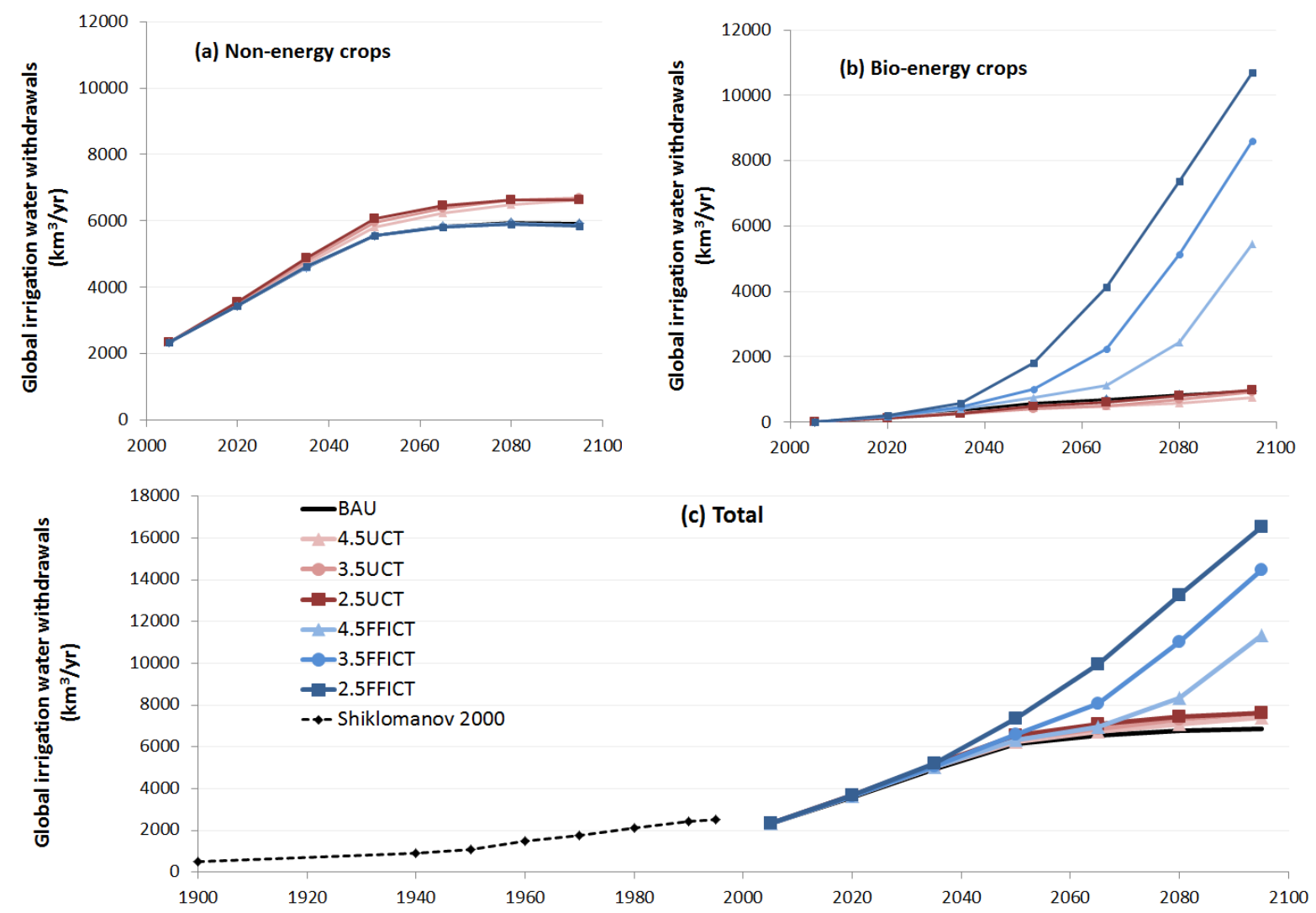

Figure 4: Projections of global irrigation water withdrawals over the $21^{\text {st }}$ century under the BAU scenario (no policy) and six climate mitigation policy scenarios; in all scenarios, the socio-economic and technological assumptions are the same and consistent with the GCAM core reference scenario

Under both policy regimes pressure to drive emissions to low levels imply rapidly increasing energy, land use, and agricultural water demand changes with the largest effects in the second half of the century.

The increasing pressure to produce bioenergy crops under the FFICT scenarios, Figure 5, drives increasing demand for irrigation to deliver bioenergy crops, Figure 4. This pressure is so large that bioenergy cropland accounts for more than half of all cropland in the policy scenarios by the end of the $21^{\text {st }}$ century, and doubles the demand for irrigation water. 

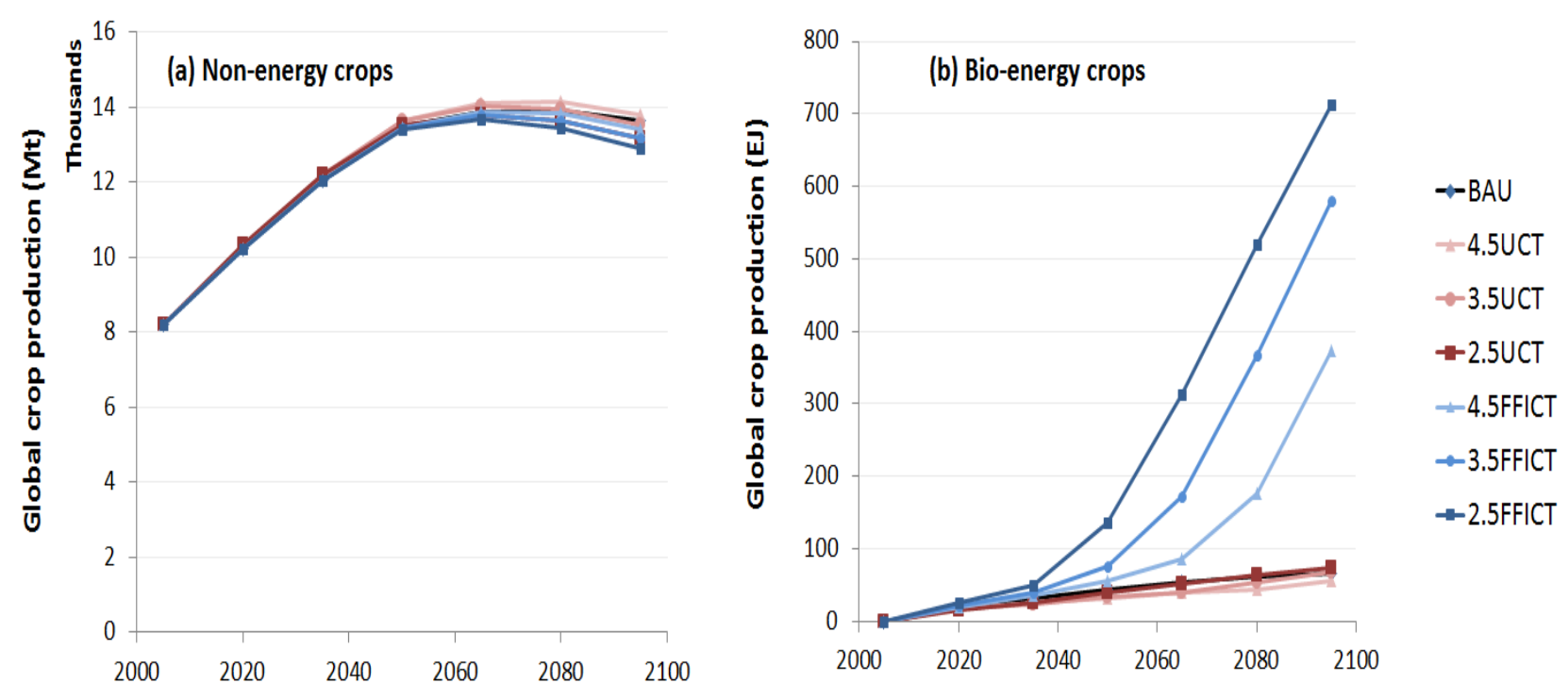

Figure 5: Projections of global productions of (a) non-energy crops and (b) bio-energy crops under the BAU and six climate mitigation policy scenarios

With more stringent FFICT mitigation policy stabilization targets, the pressure on energy systems to employ biomass with carbon capture and storage (CCS) in the power generation sector is intensified, leading to more bio-energy crop production and associated water withdrawals. Since bio-energy with CCS technology functions as a carbon sink, the FFICT scenarios also produce a significant share of bio-CCS technology in the electricity production sector to meet the emission constraint goal in the most cost-effective way.

In the FFICT scenarios, land-use change emissions are higher than under the UCT scenarios, so that fossil fuel emissions must be lower in the FFICT scenarios than in the UCT scenarios to meet the same radiative forcing goal (Figure 3).

The stringency of global emissions mitigation policy is an important factor affecting water withdrawal. With more stringent stabilization targets for both the UCT and FFICT scenarios, the total global irrigation water withdrawal increases in 2095 as compared to the reference scenario (Figure 6), while the marginal increase in withdrawals for each stabilization target differs between the two tax regimes. The increase in water withdrawals in 2095 is relatively small $(<11 \%)$ between the reference scenario and the most stringent UCT stabilization scenario, while the value is $141 \%$ under the most stringent FFICT scenario. Thus, depending on the adopted tax regime in GCAM and, consequently, the prevalence of bio-energy in the energy system portfolio, the effect of climate change mitigation policies can range from little change to as much as a doubling of total irrigation water withdrawals. The latter would have profound implications to water management practices and the sufficiency of water resources for all competing water users of future generations. 


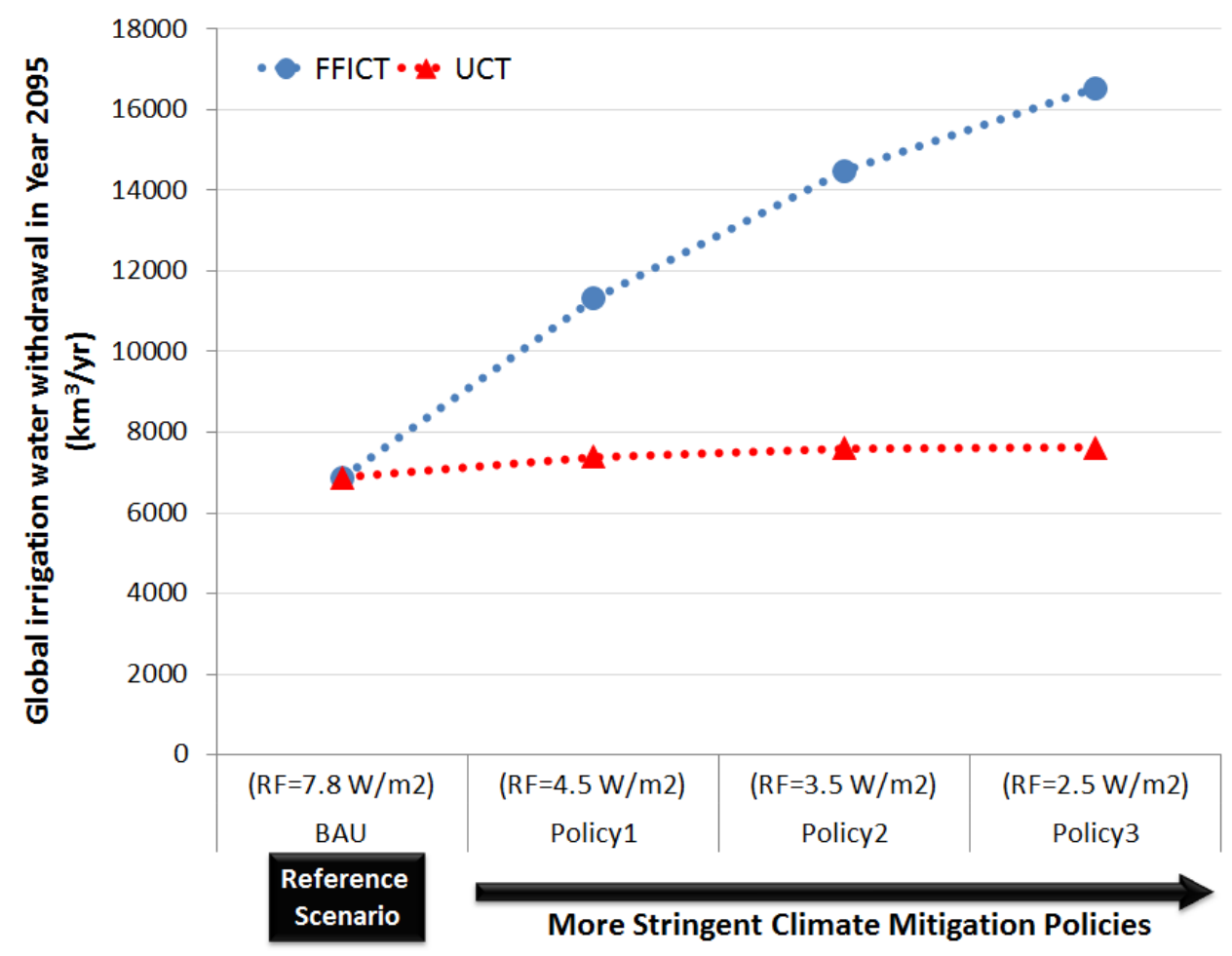

Figure 6: Total global irrigation water withdrawals in year 2095 under the BAU and six climate mitigation policy scenarios

The FFICT scenarios generate extremely high demands for fresh water withdrawals. Under the most stringent FFICT scenario, global irrigation water withdrawals increase from $2,328 \mathrm{~km}^{3} / \mathrm{yr}$. in 2005 to $16,538 \mathrm{~km}^{3} / \mathrm{yr}$. in 2095 . These values are large compared with potential water availability.

Postel et al. (1996) divided their estimate of the global mean annual runoff volume of 40,700 $\mathrm{km}^{3} /$ year to $7,774 \mathrm{~km}^{3} /$ year in remote flows that are inaccessible to human use, $20,426 \mathrm{~km}^{3} /$ year of un-captured floodwater that flows directly to the world oceans, and only the remaining 12,500 $\mathrm{km}^{3} /$ year as geographically and temporally accessible runoff, of which $2,350 \mathrm{~km}^{3} /$ year is needed for in-stream water uses. Thus, society has access to an annual renewable water volume of approximately $10,150 \mathrm{~km}^{3} /$ year.

Although this quantity may have increased over the past two decades with new reservoir storage capacity, especially in developing regions, it suggests that all FFICT scenarios are potentially infeasible when considering other growing water demands (e.g., domestic, industrial, and energy) due to the projected growth in population and energy demand. In other words, the scenario will likely run out of water to grow biomass before it runs out of land to deforest. 


\subsection{Efficiency of Water Delivery}

The extremely high withdrawal rates that occur under the FFICT scenarios call into question their physical feasibility using present agricultural water delivery technology ${ }^{2}$. In this section we investigate the implications of improving the efficiency of water delivery by agricultural irrigation systems. To the extent that such improvements in efficiency allow for agricultural systems to deliver water directly to the plant rather than losing it to the atmosphere, more efficient systems could reduce water withdrawals significantly. ${ }^{3}$

To test the implications of relaxing our assumption of constant irrigation efficiencies, we assume that the efficiency of irrigation water delivery for each region increases at $0.5 \%$ /year up to a maximum efficiency of 0.7 , which is the highest value currently for Australia and Canada. No further improvement in efficiency has been assumed for these two regions. Figure 7 compares irrigation water withdrawals across the constant efficiency and increasing efficiency scenarios.

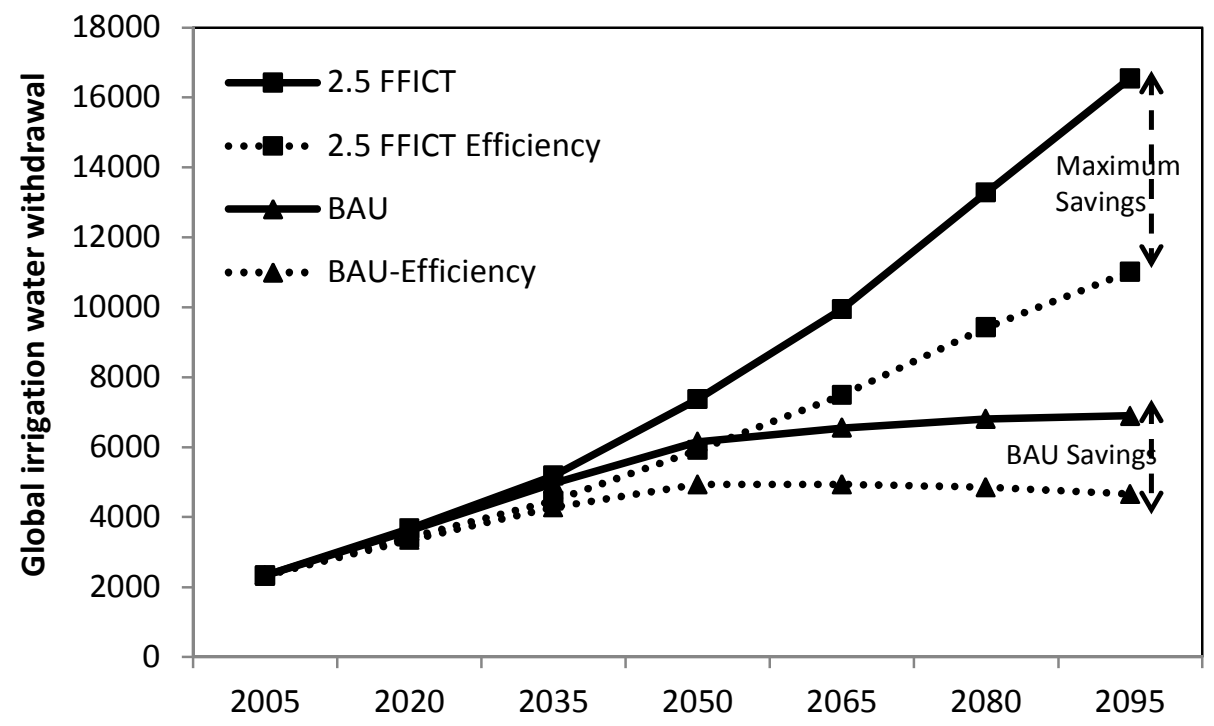

Figure 7: Global irrigation water withdrawals under constant and increasing irrigation water delivery efficiency

With the assumption of constant efficiency, irrigation water withdrawals increase from 2,332 $\mathrm{km}^{3}$ in 2005 to $6,155 \mathrm{~km}^{3}$ in 2050 and $6,891 \mathrm{~km}^{3}$ in 2095 in our reference, no-climate-policy scenario. The corresponding numbers for the increasing efficiency scenario are $4,939 \mathrm{~km}^{3}$ in 2050 and $4,661 \mathrm{~km}^{3}$ in 2095 . Thus, increasing irrigation water delivery efficiency could lead to water-savings of $20 \%\left(1,216 \mathrm{~km}^{3}\right)$ by 2050 and as much as $32 \%\left(2,230 \mathrm{~km}^{3}\right)$ by 2095 .

\footnotetext{
${ }^{2}$ There are numerous other reasons to doubt the political feasibility of such scenarios. However, we make no attempt to estimate the probability of political actions of any kind in this paper.

${ }^{3}$ We have not tried to estimate the degree to which inefficient systems simply pass water on to the next customer, as opposed to losing it to the atmosphere, and therefore some increases in efficiency could have smaller effects on water consumption than on withdrawals.
} 
The magnitude of savings varies significantly across regions. Southeast Asia and China have huge potential for reducing their irrigation water withdrawals, because they have a high irrigation consumption as well as low irrigation water delivery efficiency (0.35). Further, India and Latin America can save substantial volumes, although for different reasons: India has high water delivery efficiency (0.54) and very high water withdrawals for irrigation; therefore, even a small increase in efficiency can yield significant savings; in contrast, Latin America has a much lower share of global irrigation water withdrawals and associated consumption, but its irrigation water delivery efficiency is also very low (0.24). Hence there is a high potential to increase its efficiency and thereby achieve substantial water savings.

The FFICT scenarios benefit most from improved efficiency as their demands are highest. Global water withdrawals under the 2.5 FFICT scenario are reduced by $1,454 \mathrm{~km}^{3}$ in 2050 and $5,524 \mathrm{~km}^{3}$ in 2095 through increasing water delivery efficiency, though the savings would be similar to that under reference scenario in percentage terms. Even with our hypothesized improvements, however, the 2.5 FFICT scenario lie above the estimated total available supply estimated by Postel et al. (2006).

\subsection{Regional Implications of Emissions Mitigation Scenarios}

Figure 8 shows the spatial distribution of global irrigation water withdrawals for bio-energy crops at the AEZ scale (151 regions globally) under the FFICT2.5 climate mitigation policy scenario in year 2095 .

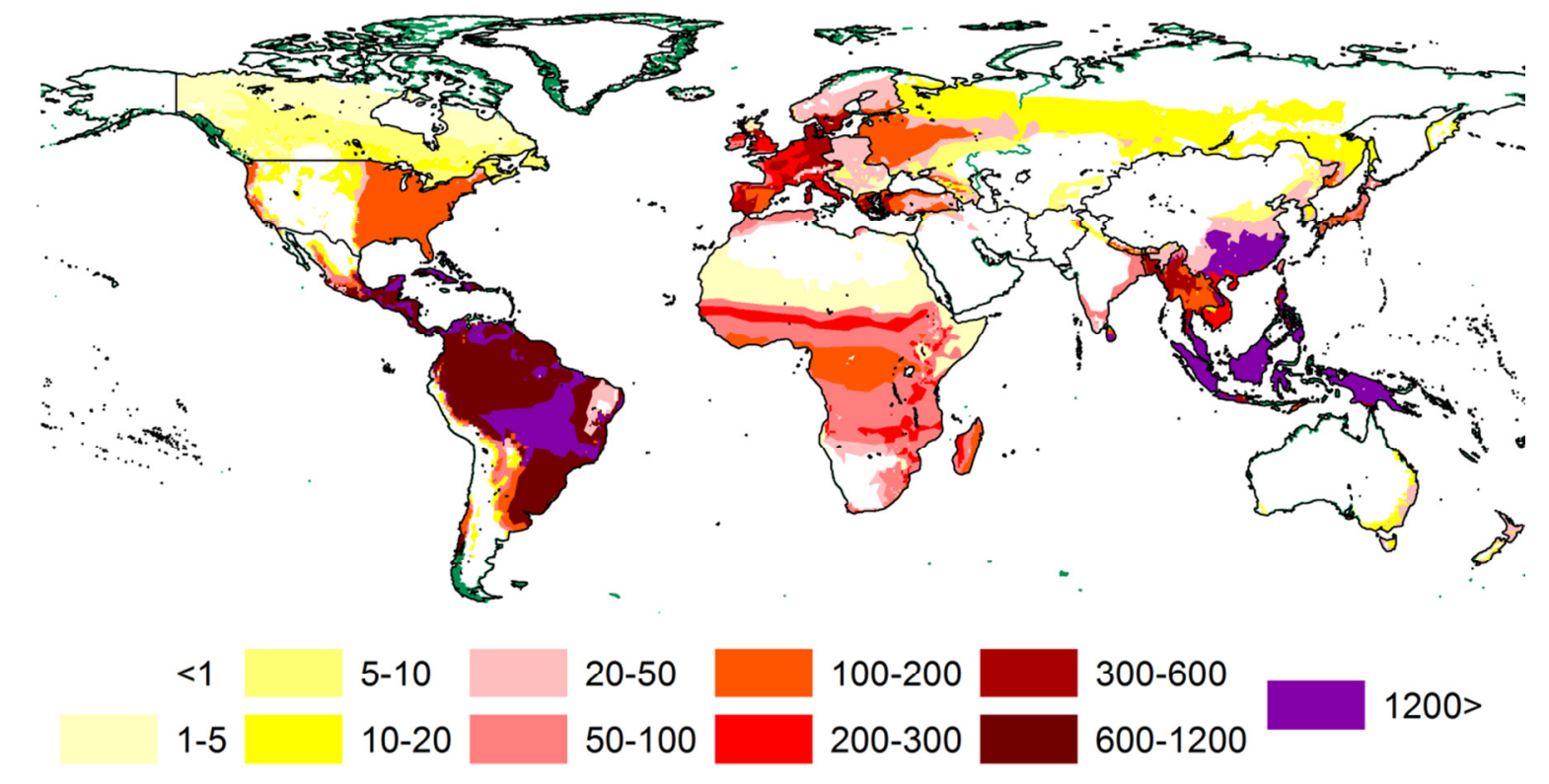

Figure 8: Spatial maps of global irrigation water withdrawals for bio-energy crops at the AEZ scale (151 regions globally) under the FFICT2.5 climate mitigation policy scenario in year 2095 
Parts of central Latin America would be intensively cultivated with bio-energy crops leading to high water withdrawals in 2095, and displacing unmanaged forests and pastures. China and parts of south-east Asia also become significant biomass producers and the associated demand for irrigation water would therefore be concentrated in these regions. The projected proliferation of bio-energy productions in these economies could induce numerous social, economic, and environmental consequences, and severe competitions for water and land. In general Asian economies, already utilizing large fractions of available water could see significant increases in demands for agricultural water uses.

\section{Conclusions}

This study considers potential implications of climate policies to reduce greenhouse gas emissions potential impact on agricultural water demands within an integrated, closely coupled, energy-economy-land-and-water modeling framework. Climate policy can affect aggregate agricultural water demand through two pathways in this analysis. The first is through bioenergy production. Since bioenergy is a renewable energy form it has minimal direct emissions, though a substantial literature exists examining indirect emissions. The second pathway is through the total production of crops. As crop demands increase, so too do demands for water, particularly as crops push into areas with lower dry land yields.

We consider two alternative policy architectures - the first, UCT taxed all carbon emissions, fossil fuel and terrestrial, at the same rate. The second, FFICT taxed only fossil fuel and industrial carbon emissions.

In the FFICT scenarios demands for irrigation water grew rapidly throughout the century, driven by the runaway expansion in the use of bioenergy. This was particularly acute in developing economies, notably China, India, Latin America and Southeast Asia (Figure 2). These demands are of sufficient scale that they call into question whether the bioenergy production in the scenario could ever be produced. Close to half of the global annual runoff would be required for irrigation. In other words, this scenario is likely to run out of water before it runs out of forest. Yet, it is worth noting that the results reported here are within the range observed in the literature of long-term global emissions mitigation (SRREN, 2011). Brendes (2002) presents a summary of potential contribution of bio-energy from 17 global studies, and estimates go up to $400 \mathrm{EJ}$ in 2100, with many studies estimating bioenergy contribution above 200 EJ in 2095.

We explored the degree to which improved efficiency of water delivery and use could ameliorate demand growth. We found that substantial savings were potentially available (Figure 7) - 20\% in $2050\left(1,216 \mathrm{~km}^{3}\right)$ and $32 \%\left(2,232 \mathrm{~km}^{3}\right)$ in 2095-particularly in Southeast Asia, China, Latin America and India, but noted that in the FFICT policy scenario, these even with more efficient water delivery and irrigation systems, demands remained a factor of five larger than 2005 levels.

Our UCT policy scenarios exhibited dramatically different characteristics. Taxation of terrestrial carbon emissions (and subsidy of carbon sequestration) produced rapid net afforestation, reducing the land area available for cultivation. Water demands for bioenergy production was actually lower than in the reference scenario, however total water demands did increase slightly, largely through the changing pattern of cropping. 


\section{Limitations and Future Work}

The strength of this study is the integrated nature of the energy, agriculture, land use, and climate systems. The use of the GCAM integrated assessment model provides a closely coupled, internally consistent frame of analysis. However, there are several limitations to the analysis. First, we only consider agricultural water withdrawal demands. We do not consider other water demands such as those deriving from direct energy use, industrial use, domestic use and commitments to environment, navigation, and other claimants. Future research will consider this broader scope.

Climate and $\mathrm{CO}_{2}$ feedbacks are not considered to allow us to focus explicitly on the policy impacts on agricultural water demands. Both will potentially affect agricultural water consumption. For example, increased concentrations of carbon dioxide in the atmosphere can be expected to increase the water use efficiency of plants, particularly C3 plants, (Leaky, 2009). Shifts in temperature zones and precipitation patterns may also change crop virtual water contents - an effect not included in the present study.

The study establishes the general spatial pattern and magnitude of long term irrigation water withdrawals, and highlights some important issues to set a context for future research directions and understanding of future global water challenges. But, our downscaling techniques provide only one possible spatial disaggregation of water demands.

Finally, while we have endogenously calculated water demands, no attempt has been made to detail the consequences of water-stress. As was noted in our conclusions section above, the water demands associated with our FFICT policy scenario were so large as to be impossible without very large scale augmentation of natural fresh-water supplies through for example massive desalinization. Water constraints will doubtless exert important feedbacks on energy and agricultural systems and a high priority in model development is the explicit allocation of water to competing uses with explicit consequences for water users.

\section{Acknowledgments}

The authors are grateful for research support provided by the Integrated Assessment Research Program in the Office of Science of the U.S. Department of Energy under Contract No. DEAC05-76RL01830. The views and opinions expressed in this paper are those of the authors alone. 


\section{References}

- Alcamo J, Florke M, Marker M. 2007. Future long term changes in global water resources driven by socio-economic and climatic changes. Hydrological Sciences Journal $52,247-275$

- Azar C. 2005. Emerging scarcities - Bioenergy-food competition in a carbon constrained world. In Scarcity and Growth Revisited, Resources for the Future (Simpson, R., et al., eds), pp 98-119

- Brendes G. 2002. Bioenergy and water- the implications of large scale bioenergy production for water use and supply. Global Environmental Change, 12, pp. 253-271

- Brendes G. 2008. Water demand for global bioenergy production: trends, risks and opportunities. WBGU, Berlin

- Bruinsma J. 2009. The resource outlook to 2050: How much do land, water and crop yields need to increase by 2050. Expert meeting on how to feed the world in 2050, Food and Agricultural Organization of the United Nations Economic and Social Development Department

- Calzadilla A, Rehdanz K, Tol RSJ. 2010. The economic impact of more sustainable water use in agriculture: A computable general equilibrium analysis. Journal of Hydrology, Vol. 384

- Calvin K, Edmonds J, Bond-Lamberty B, Clarke L, Kim SH, Kyle P, Smith SJ, Thomson A, Wise M. 2009. 2.6: Limiting climate change to $450 \mathrm{ppm} \mathrm{CO} 2$ equivalent in the $21 \mathrm{st}$ century. Energy Economics 31, Vol. 2

- Chapagain AK and Hoekstra AY. 2004. Water footprints of nations. UNESCO-IHE Institute for Water Education, Research report series no. 16

- Clarke L, Lurz J, Wise M, Edmonds J, Kim S, Pitcher H and Smith S. 2007. Model Documentation for the MiniCAM Climate Change Science Program Stabilization Scenarios. Pacific Northwest National Laboratory Technical Report PNNL-16735, CCSP Product 2.1a; U.S. Department of Energy: Richland, WA, USA.

- Clarke, L., J. Edmonds, V. Krey, R. Richels, S. Rose, M. Tavoni, 2009, International Climate Policy Architectures: Overview of the EMF 22 International Scenarios, Energy Economics, Volume 31, Supplement 2, December 2009, Pages S64-S81, International, U.S. and E.U. Climate Change Control Scenarios: Results from EMF 22.

- de Fraiture C and Wichelns D. 2010. Satisfying future water demands for agriculture. Agriculture water management, Vol. 97, Issue 4, pp. 502-511 
- Döll P and Seibert S. 2002. Global modeling of irrigation water requirements. Water resources research, Vol. 38

- Döll, P., Kaspar, F., \& Lehner, B. (2003). A global hydrological model for deriving water availability indicators: model tuning and validation. Journal of Hydrology, 270(1-2), 105134. doi: 10.1016/s0022-1694(02)00283-4

- Döll P. 2004. Impact of climate change and variability on irrigation requirements: A global perspective. Climatic Change, Vol. 54, 269-293

- Edmonds J and Reilly J. 1985. Global Energy: Assessing the Future. Oxford University Press, New York

- Edmonds J, Calvin K, Clarke L, Kyle P and Wise M. 2012. Energy and technology lessons since Rio. Energy Economics 34, S7-S14

- Ehhalt D et al. 2001. Chapter 4. Atmospheric Chemistry and Greenhouse Gases In: Climate Change 2001: The Scientific Basis (Houghton, J. T. et al. eds, Cambridge, U.K.: Cambridge University Press)

- Fader M, Rost S, Muller C, Bondeau A, Gerten D. 2010. Virtual water content of temperate cereals and maize: Present and potential future patterns. Journal of Hydrology, Vol. 384

- FAO (Food and Agriculture Organization). 2003. Agriculture, food and water. A contribution to the World Water Development report

- Fischer G, Tubiello FN, van Velthuizen H, Wiberg DA. 2007. Climate change impacts on irrigation water requirement: Effects of mitigation, 1990-2080. Technological Forecasting and Social Change 74, 1083-1107

- Geist HJ and Lambin EF. 2002. Proximate causes and underlying driving forces of tropical deforestation. BioScience, Vol. 52, No. 2, p. 45

- Gerbens-Leenes PW, Hoekstra AY and van der Meer TH. 2009. The water footprint of energy from biomass: a quantitative assessment and consequences of an increasing share of bioenergy in energy supply. Ecological Economics, 68, pp. 1052-1060

- Gillingham KT, Smith SJ and Sands RD. 2008. Impact of bioenergy crops in a carbon dioxide constrained world: an application of the MiniCAM energy-agriculture and land use model. Mitigation and Adaptation Strategies for Global Change 13, pp. 675-701 
- Grassi G, den Elzen MGJ, Hof AF, Pilli R and Federici S. 2012. The role of land use, land use change and forestry sector in achieving Annex I reduction pledges. Climatic Change

- Hanasaki N, Inuzuka T, Kanae S, Oki T. 2010. An estimation of global virtual water flow and sources of water withdrawal for major crops and livestock products using a global hydrological model. Journal of Hydrology, Vol. 384

- Hanjra M A and Qureshi M E. 2010. Global water crisis and food security in an era of climate change. Food Policy, Vol 35, Issue 5, pp. 365-377

- Hoekstra AY and Mekonnen MM. 2012. The water footprint of humanity. Proceedings of the National Academy of Sciences of the United States of America, www.pnas.org/cgi/doi/10.1073/pnas.1109936109

- Hotelling H. 1931. The Economics of Exhaustible Resources. Journal of Political Economy 39:137-175.

- IPCC-AR4, 2007. Climate change 2007: Synthesis report, contribution of working groups I, II and III to the fourth assessment report of the intergovernmental panel on climate change, core writing team, Pachauri, R.K. and Reisinger, A. (Eds.), IPCC, Geneva, Switzerland. pp 104

- $\quad$ Kyle P, Luckow P, Calvin K, Emanuel W, Nathan M, and Zhou Y. 2011. GCAM 3.0 Agriculture and Land Use: Data Sources and Methods. http://wiki.umd.edu/gcam/images/2/25/GCAM AgLU Data Documentation.pdf.

- Leaky ADB, Ainsworth EA, Bernacchi CJ, Rogers A, Long SP and Ort, DR. 2009. Elevated $\mathrm{CO}_{2}$ effects on plant carbon, nitrogen, and water relations: six important lessons from FACE. Journal of Experimental Botany, Vol. 60, No. 10, pp. 2859-2876

- Liu J and Yang H. 2010. Spatially explicit assessment of global consumptive water use in cropland. Journal of Hydrology, Vol. 384

- Luckow P, Wise MA, Dooley JJ, Kim SH. 2010. Large-scale utilization of biomass energy and carbon dioxide capture and storage in the transport and electricity sectors under stringent $\mathrm{CO}_{2}$ concentration limit scenarios. International Journal of Greenhouse Gas Control 4:865-877.

- McCalla AF. Challenges to world agriculture in the $21^{\text {st }}$ Century. Update, Agriculture and Resource Economics, University of California, Davis, Vol. 4, No. 3,

- McCarl, B.A. and U.A. Schneider. 2001. Greenhouse gas mitigation in U.S. agriculture and forestry, Science, 294, pp. 2481-2482. 
- Mekonnen, M.M. and Hoekstra, A.Y. (2010) The green, blue and grey water footprint of crops and derived crop products, Value of Water Research Report Series No. 47, UNESCO-IHE, Delft, the Netherlands.

- Mekonnen MM and Hoekstra AY. 2011. The green, blue and grey water footprint of crops and derived crop products. Hydrology and Earth System Sciences, 15, pp. 15771600

- Melillo JM, Reilly JM, Kicklighter DW, Gurgel AC, Cronin TW, Paltsev, Felzer BS, Wang X, Sokolov AP, and Schlosser CA. 2009. Indirect Emissions from Biofuels: How Important? Science 326(5958):1397-1399.

- Molden, D. (Ed.) (2007), Water for Food Water for Life: A Comprehensive Assessment of Water Management in Agriculture, chap. 2, Trends in water and agricultural development, pp. 57-89, Earthscan, London.

- Monfreda C, Ramankutty N, Hertel T. 2009. Global Agricultural Land Use Data for Climate Change Analysis. . in Hertel T, Rose S, Tol R (eds.) Economic Analysis of Land Usein Global Climate Change Policy. Routledge.

- Nakicenovic N, Swart R (Eds.). 2000. IPCC Special Report on Emissions Scenarios. Cambridge University Press: Cambridge

- Ozdogan, M. 2011. Exploring the potential contribution of irrigation to global agriculture primary productivity. Global Biogeochemical Cycles, Vol. 25, GB3016

- Peck S, and Wan W. 1996. Analytic Solutions of Simple Greenhouse Gas Emission Models. in Van Ierland E, Gorka K (eds.) Economics of Atmospheric Pollution. Springer Verlag, New York.

- Postel S. 1998. Water for food production: will there be enough in 2025? BioScience, Vol. 48, No. 8, pp. 629-637

- Postel, S. L., Daily, G. C., \& Ehrlich, P. R. (1996). Human Appropriation of Renewable Fresh Water. Science, 271(5250), 785-788. doi: 10.1126/science.271.5250.785

- Rokityanskiya, Dmitry, Pablo C. Benítezb, Florian Kraxnera, Ian McCalluma, Michael Obersteinera, Ewald Rametsteinera, Yoshiki Yamagatac. 2007. Geographically explicit global modeling of land-use change, carbon sequestration, and biomass supply, Technological Forecasting and Social Change, 74(7):1057-1082.

- Rockstrom J, Falkenmark M, Karlberg L, Hoff H, Rost S and Gerten D. 2009. Future water availability for global food production: The potential of green water for increasing resilience to global change. Water Resource Research, 45 
- Rosegrant MW, Cai X and Cline SA. 2002. Global water outlook to 2025: averting an impending crisis. International Food Policy Research Institute and International Institute of Water Management

- Rosegrant, M.W., Msangi, S., Ringler, C., Sulser, T.B., Zhu, T., Cline, S.A., 2008. International Model for Policy Analysis of Agricultural Commodities and Trade (IMPACT): Model Description. International Food Policy Research Institute, Washington, DC. <http://www.ifpri.org/themes/impact/impactwater.pdf>.

- Rost S, Gerten D, Bondeau A, Lucht W, Rohwer J, Schaphoff S. 2008. Agriculture green and blue water consumption and its influence on the global water system. Water Resources Research, Vol. 44

- Syri S, Lehtila A, Ekholm T, Savolainen I, Holttinen H, and Peltola E. 2008. Global energy and emission scenarios for effective climate change mitigation- Deterministic and stochastic scenarios with the TIAM model. International Journal of Greenhouse Gas Control, Vol. 2

- Seibert T and Döll P. 2010. Quantifying blue and green virtual water contents in global crop water production as well as potential production losses without irrigation. Journal of Hydrology, 384, pp. 198-217

- Shen Y, Oki T, Utsumi N, Kanae S, Hanasaki N. 2008. Projection of future world water resources under SRES scenarios: water withdrawal. Hydrological Sciences Journal 53, $11-33$

- Shiklomanov IA, 2000. World water use \& water availability. State Hydrological Institute (SHI). (http://webworld.unesco.org/water/ihp/db/shiklomanov/part'3/ Read'me.html)

- SRREN. 2012. IPCC Special Report on Renewable Energy Sources and Climate Change Mitigation. (Eds.) Edenhofer et al.

- The 2030 Water Resources Group. 2009. Charting our water future: economic frameworks to inform decision making. Accessed on January 2011 from http://www.mckinsey.com/en/Client Service/Sustainability/Latest thinking/Charting o ur water future.aspx

- Thomson A, Calvin K, Smith S, Kyle G, Volke A, Patel P, Delgado-Arias S, BondLamberty B, Wise M, Clarke L, Edmonds J (2011) RCP4.5: a pathway for stabilization of radiative forcing by 2100 . Climatic Change 109:77-94. 
- Wise, M. A. and Calvin, K. 2011. GCAM 3.0 Agriculture and Land Use Modeling: Technical Description of Modeling Approach. https://wiki.umd.edu/gcam/images/8/87/GCAM3AGTechDescript12 5 11.pdf

- Wise MA, Calvin KV, Thomson AM, Clarke LE, Bond-Lamberty B, Sands RD, Smith SJ, Janetos AJ and Edmonds JA. 2009. The implications of limiting CO2 concentrations for land use and energy. Science 324, 1183

- Wisser D, Frolking S, Douglas EM, Fekete BM, Vorosmarty CJ and Schumann AH. 2008. Global irrigation water demand: uncertainties arising from agricultural and climate data sets. Geophysical Research Letters, Vol. 35

- Wisser D, Frolking S, Douglas EM, Fekete BM, Schumann AH, Vorosmarty CJ. 2010. The significance of local water resources captured in small reservoirs for crop production- A global scale analysis. Journal of Hydrology, Vol. 384

- http://www.fao.org/hr/water/aquastat/water use agr/index5.stm , as accessed on August 2, 2011

- Van Vuuren D, JA Edmonds, M Kainuma, K Riahi, AM Thomson, KA Hibbard, G Hurtt, T Kram, V Krey, JF Lamarque, Matsui, M Meinhausen, N Nakicenovic, SJ Smith, and SK Rose. 2011. "The Representative Concentration Pathways: An Overview." Climatic Change. 109:5-31.

- Varghese, S. (2007), Biofuels and global water challenges, Rep., Institute for Agriculture Trade and Policy, USA. 